\title{
Perspektywy rozwoju robotyzacji spawania łukowego w osłonie gazowej
}

\author{
Prospects for the development of robotic \\ arc welding with shielding gas
}

\section{Streszczenie}

W artykule podjęto tematykę zmian w podejściu do procesów robotyzacji $w$ aspekcie spawania łukowego w okresie zmian ustrojowych oraz współczesnych wymagań stawianych stanowiskom zrobotyzowanym. Przedstawiono również doświadczenia i spostrzeżenia autora o wieloletnim doświadczeniu w robotyzacji procesów spawalniczych.

\begin{abstract}
The article deals with changes in the approach to the processes in terms of robotic arc welding during the political changes and the requirements of modern robotic applications. The article presents the author's experience and insights of many years of experience in the robotic welding processes.
\end{abstract}

\section{Garść wspomnień}

Roboty zastępujące ludzi były początkowo obiektem science fiction i podobnie jak inne urządzenia zaistniały najpierw w wyobraźni ludzkiej. Samo określenie robot pochodzi najprawdopodobniej ze sztuki czeskiego pisarza Karola Capka pt. „Świat Robotów". Wraz z rozwojem techniki napędów oraz techniki sterowania podjęto próby skonstruowania maszyn przypominających mechanikę funkcjonowania człowieka, a więc maszyna taka powinna mieć trzy ruchome osie robocze podstawy odwzorowujące ruchy tułowia człowieka oraz trzy ruchome osie robocze odwzorowujące ruchy ręki człowieka. Wysiłki konstruktorów zakończyły się sukcesem i do dzisiaj kraje o wysokim zaawansowaniu technologicznym prowadzą bardzo drogie badania zmierzające do udoskonalenia techniki robotowej i ciągle powiększane są obszary zastosowania robotów.

Po raz pierwszy miałem możność zetknięcia się $z$ techniką robotyzacji $w$ połowie lat 70 . ub.w. Uczestniczyłem wtedy jako młody inżynier spawalnik z Fabryki Wagonów Świdnica, chyba trochę przez przypadek, w sympozjum naukowo-technicznym w Warszawie, zorganizowanym przez Instytut

Andrzej Siennicki - Cloos Polska.
Mechaniki Precyzyjnej z udziałem firmy Unimate ze Stanów Zjednoczonych. Sympozjum to było adresowane do decydentów zarządzających polskim przemysłem, którzy mieli plany gruntownej modernizacji technik i technologii wytwarzania przede wszystkim w sektorze przemysłu maszynowego. Trzeba podkreślić, że pod koniec lat 70 . Polska zakupiła licencję na wytwarzanie dwóch typów robotów IRB 6 oraz IRB 60 od szwedzkiej firmy ASEA. Działo się to w okresie, kiedy Ministerstwem Przemysłu Maszynowego zarządzał świdniczanin dr inż. Aleksander Kopeć. Powstały również krajowe konstrukcje robotów.

Podczas sympozjum przedstawiciel firmy Unimate wyjaśnił przyczyny, dla których w Stanach Zjednoczonych po raz pierwszy zastosowano roboty przemysłowe. Okazało się, że siłą napędową, która spowodowała powstanie robotów, była „walka klas", tj. klasy przedsiębiorców z klasą robotniczą, z tym że trochę inaczej niż $w$ teorii Marksa, walka ta zakończyła się zwycięstwem przedsiębiorców, m.in. dzięki rozwiązaniom firmy Unimate.

W amerykańskim przemyśle samochodowym przy obsłudze pras zatrudniono ludzi o stosunkowo niskim wykształceniu, którzy ze względu na dużą uciążliwość wykonywanej pracy mieli wygórowane żądania płacowe. Ponadto stwierdzono dużą liczbę wypadków przy pracy. Uważano, że część tych wypadków była aranżowana celowo, w celu wyłudzenia 
odszkodowań. Unimate wyeliminowała te problemy przez wprowadzenie do amerykańskich tłoczni robotów, które zastąpiły operatorów pras. Pamiętam historyczne zdjęcie robota ze sterownikiem w postaci ogromnego bębna, na którym był zakodowany kilkuminutowy program roboczy. Sympozjum to zrobiło na mnie dosyć duże wrażenie i zastanawiałem się, kiedy w moim zakładzie roboty zastąpią pracę spawaczy. Powodem zastosowania robotów miało być zwiększenie potencjału produkcyjnego zakładu i odsunięcie ludzi od szkodliwych dla zdrowia warunków pracy. Później dowiedziałem się, że mniej więcej w tym samym okresie inżynier Erwin Cloos, przebywając na targach przemysłowych w Stanach Zjednoczonych, wpadł na pomysł, aby zakupić od firmy Unimate robot przemysłowy i zastosować go do spawania w osłonie gazów ochronnych metodą MIG/MAG.

Firma Carl Cloos Schweisstechnik $\mathrm{GmbH}$ od połowy lat pięćdziesiątych ubiegłego wieku rozwijała produkcję urządzeń do spawania w osłonach gazowych. Obok doskonałych jak na owe czasy półautomatów spawalniczych Cloos projektował i budował automaty do spawania metodą MIG/ MAG, wykorzystując napędy liniowe i obrotowe oraz sterowanie oparte na stycznikach, przekaźnikach i krzywkach. Robot stwarzał możliwości rozszerzenia automatyzacji przy wykonywaniu spoin wg krzywoliniowych trajektorii oraz takich spoin, których wykonanie na automacie było niemożliwe lub nieopłacalne.

Próby sprzężenia robota Unimate z półautomatem Cloosa wykazały, że opanowanie procesu spawania przez robota wymaga zbudowania urządzenia spełniającego wymagania wynikające $z$ procesu spawania. Robot Unimate tych cech nie miał, ponieważ był manipulatorem z napędami hydraulicznymi, ale umożliwił opracowanie założeń konstrukcyjnych dla robota spawalniczego. Cloos opracował własny produkt pod nazwą robot przemysłowy ROMAT, który od 1978 r. po wielu modyfikacjach jest dostępny na rynku i ciągle prowadzone są prace nad jego udoskonaleniem. W ubiegłym roku nastąpiło odnowienie marki i robot ten po gruntownej modernizacji występuje pod nazwą Qirox.

W latach 70. i 80. w Europie, a przede wszystkim w Japonii, powstały konstrukcje robotów, które z mniejszym lub większym powodzeniem stosowano do różnych zadań. Pamiętam również, że w jednej z zachodnich firm produkujących półautomaty prowadzono badania nad aplikacjami spawalniczymi robotów TRALFA i ASEA. Roboty te były typowymi robotami manipulacyjnymi i ich przydatność do spawania była ograniczona.

W kraju w toruńskim APATORZE sprawdzono aplikacje spawalnicze licencyjnych robotów ASEA. Możliwości spawalnicze i programowe tych robotów uniemożliwiły ich zastosowanie w produkcji wagonów na szerszą skalę.
Pytanie, czy roboty moga skutecznie zastapić spawaczy w procesie produkcji wagonów towarowych, nadal pozostało bez odpowiedzi. Należało więc poszukiwać informacji również o innych rozwiązaniach a nie było to łatwe. Początek lat 80 . to okres burzliwych przemian społecznych i politycznych, które nie sprzyjały rozwojowi i postępowi technicznemu.

Rozpoznanie techniczne pozwoliło mi na sformułowanie kilku wniosków warunkujących zastosowanie robotów w przemyśle budowy taboru kolejowego, które w mniejszym lub większym stopniu są aktualne również teraz.

1. Konstrukcje wagonowe wykonane $z$ profili hutniczych i detali wycinanych tlenowo z blach nie zapewniają powtarzalności umiejscowienia złącza spawanego w przestrzeni pracy robota. Wynika to z tolerancji wykonania wyrobów walcowanych i giętych oraz z dokładności procesu cięcia tlenowego (cięcia plazmą i laserem nie stosowano w tym czasie). W związku z tym należy zastosować roboty adaptacyjne, które przed spawaniem wykonują pomiar rzeczywistego położenia spoiny, a podczas spawania będą śledzić miejsce ułożenia spoiny.

2. Sterowanie ruchami robota oraz sterowanie parametrami spawania powinno być sprzężone i powinno umożliwiać:

- zmianę parametrów na długości spoiny oraz wypełnienie krateru,

- wykonywanie spoin wielowarstwowych,

- wykonywanie spoin ruchem zakosowym,

- optymalizowanie parametrów w czasie spawania.

3. Praca na stanowisku zrobotyzowanym powinna być tak zorganizowana, żeby robot realizował zaprogramowane zadania produkcyjne bez udziału operatora, który w tym czasie wykonuje inne prace, np. montaż, sczepianie, załadunek części, a w proces realizacji programu wkracza wtedy, kiedy nastąpiło zatrzymanie awaryjne lub robot zasygnalizował zakończenie spawania. Takie założenie wymagało wykonawstwa odpowiednich przyrządów do montażu i spawania podzespołów na robocie oraz zastosowania urządzeń peryferyjnych sterowanych przez robot, służących do pozycjonowania spawanego wyrobu.

4. Aby robotyzacja procesu spawania przyniosła zamierzone efekty, musi być wprowadzona przy pełnej świadomości jej zalet oraz ograniczeń. Konieczne jest przede wszystkim przeszkolenie technologów, konstruktorów, programistów, operatorów robotów i spawaczy.

Pamiętam, że w Świdnickiej Fabryce Wagonów przy analizowaniu problemów robotyzacji jednym z najważniejszych był podniesiony przez Dyrekcję Zakładu problem stosunku spawaczy, a szerzej klasy robotniczej - do robotów. Wynikało to z obaw przed nieprzychylną reakcją spawaczy, konfliktami, być może strajkiem. Umiejętnie wprowadzony system wdrożenia na szczęście spowodował pełną akceptację spawaczy dla nowych procesów. 
5. Wybór partnera do współpracy w dziedzinie robotyzacji ściśle wiąże się z poprzednimi wnioskami. Chciałbym jednak zwrócić uwage na jego kluczowe znaczenie tym zakładom produkcyjnym, dla których robotyzacja nie stanowi jednorazowego zakupu, ale rozłożona jest $w$ czasie na wiele etapów. W latach 80. wybór był niewielki, co nie oznacza, że nie było konkurencji. W tym czasie brakowało spójnej filozofii w dziedzinie wdrożenia robotyzacji przy spawaniu i ważne było, aby oferta sprzedaży i wdrożenia pokrywała się z oczekiwaniami dostawcy. W Fabryce wybrano niemiecką firmę Carl Cloos Schweisstechnik, która spełniła oczekiwania użytkownika, a w późniejszym czasie nawiązała bliską współpracę w zakresie produkcji urządzeń peryferyjnych oraz $\mathrm{w}$ zorganizowaniu doświadczalno-szkoleniowego Ośrodka Robotyzacji Spawania. Dzięki ośrodkowi uzyskano darmowy dostęp do najnowszej wiedzy.

Prowadzenie dalszych prac w oparciu o te wnioski miało sens tylko w przypadku spełnienia dwóch warunków.

Pierwszym było zapewnienie środków finansowych i to w dwóch rodzajach, a mianowicie złotych polskich na sfinansowanie inwestycji i dewiz na zakup niezbędnych urządzeń. W kraju uruchomiono wtedy w Ministerstwie Przemysłu resortowy program rozwoju robotyki, którego zadaniem było centralne

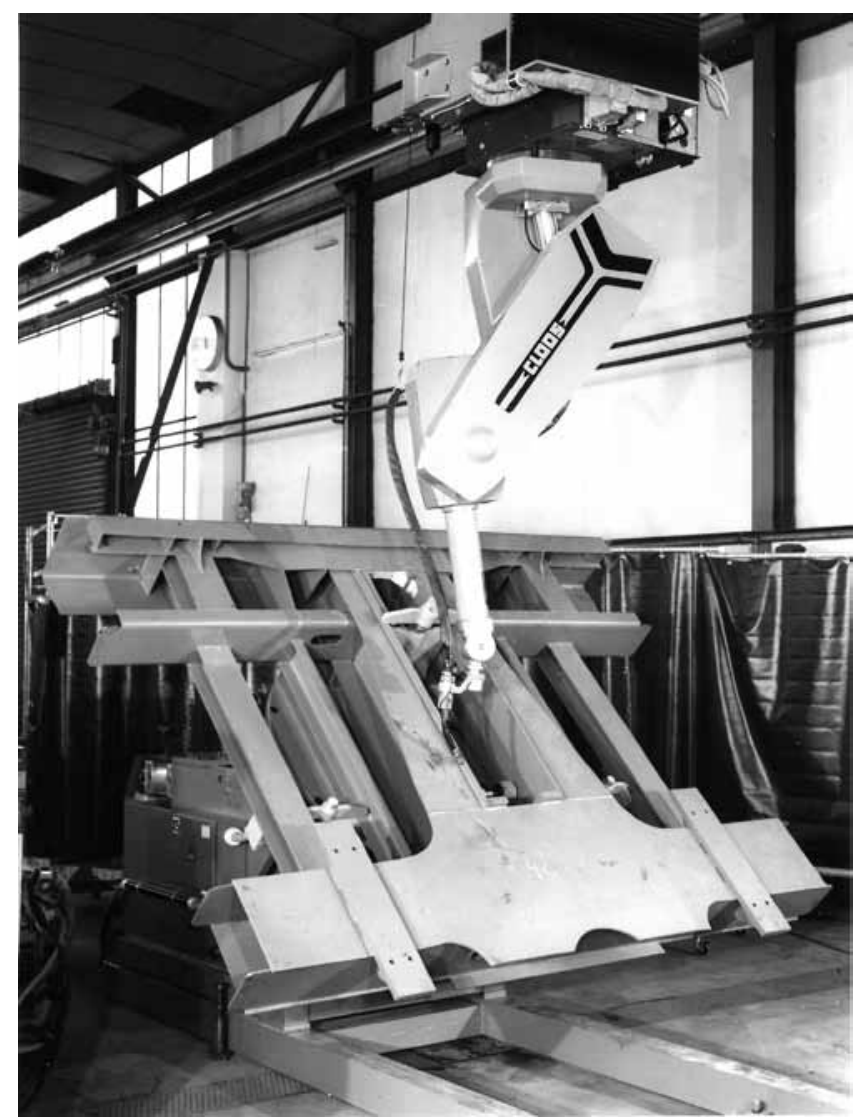

Rys. 1. Zrobotyzowane stanowisko do spawania części przedniej wagonu platformy. Projekt z roku 1987

Fig. 1. Robotic welding station of the front of the wagon platform. Draft from 1987 wspieranie i modernizacja zakładów. W ramach tego programu można było sfinansować wiele zadań. Przypomina to trochę obecne dofinansowanie z Unii Europejskiej. Większy problem stanowiło pozyskiwanie dewiz. Fabryka była w szczęśliwym położeniu, ponieważ była eksporterem do tzw. drugiego obszaru płatniczego, co oznaczało, że za sprzedane wagony i kontenery uzyskiwano środki dewizowe. Zdecydowana część tych środków musiała być sprzedana w NBP po tzw. kursie oficjalnym, ale niewielka ich część mogła zostać na koncie dewizowym, z którego za pośrednictwem centrali handlu zagranicznego można było płacić za maszyny lub za materiały do produkcji.

Drugim czynnikiem było posiadanie stabilnej, seryjnej produkcji nadającej się do robotyzacji. W przypadku gospodarki sterowanej centralnie sytuacja była wręcz komfortowa. Wagony produkowano w seriach kilku tysięcy sztuk i nakłady ponoszone na stanowiska zrobotyzowane zwracały się po kilku latach nawet w tamtych warunkach przy zaniżonej wartości kosztów robocizny.

Pod koniec lat 80. w Fabryce pracowało 6 stanowisk zrobotyzowanych $w$ linii spawania podwozi wagonów i kontenerów. Poziom techniczny zastosowanych rozwiązań był bardzo wysoki i niestandardowy, a pomysły z tamtego okresu są wykorzystywane do dzisiaj.

Niedawno widziałem stanowisko zrobotyzowane do spawania części przedniej wagonu platformy dla odbiorcy z Kanady, wykonane wg pomysłu zastosowanego w Fabryce (rys. 1). Należy podkreślić, że nawet $\mathrm{w}$ czasie załamania gospodarczego początku lat 90 . stanowiska zrobotyzowane pracowały po adaptowaniu ich do innych wyrobów.

\section{I co dalej?}

Czy w czasie kryzysu z początku lat 90 . miało sens inwestowanie $w$ robotyzację? - raczej nie. Wobec tego co zrobić z wiedzą i ludźmi, którzy opanowali dosyć unikalną jak na owe czasy wiedzę w zakresie projektowania, programowania i serwisowania zrobotyzowanych stanowisk spawalniczych? Aby nie utracić tego co osiągnięto, utworzono małą firmę o nazwie Cloos Polska, która zajmuje się usługami i handlem. Spodziewano się, że po zakończeniu kryzysu nastąpi ożywienie i przyjdzie zapotrzebowanie ze strony przemysłu na robotyzację i automatyzację procesów spawalniczych. Zapotrzebowanie przyszło, ale nie tak szybko jak oczekiwaliśmy i z innej strony. Zmieniała się struktura polskiego przemysłu i dotychczasowi potentaci w branży wagonów, samochodów ciężarowych, maszyn górniczych, maszyn budowlanych i rolniczych borykali się z problemami, ale na rynku pojawiły się małe i średnie prywatne firmy oraz filie zachodnich koncernów. W tym czasie poświęcono bardzo dużo 
czasu na popularyzację robotyzacji przez udział w targach, wystawach, konferencjach i publikowanie reklam, artykułów technicznych i artykułów sponsorowanych. Przez wiele lat firma Cloos Polska jako jedyna w Polsce prezentowała na targach zrobotyzowane stanowiska spawalnicze i konsekwentnie zamieszczała artykuły i reklamy w czasopismach spawalniczych. Obecnie na polskim rynku działają firmy, które sprzedają stanowiska zrobotyzowane zaprojektowane w oparciu o systemy z różnych firm. Przemysł motoryzacyjny importuje kompletne linie zrobotyzowane $z$ różnych krajów zachodnich bądź przenosi te linie do Polski z fabryk ulokowanych w różnych częściach świata.

Także każda uczelnia techniczna prowadzi kierunki automatyzacji, robotyzacji bądź mechatroniki, a na wydziałach o innym profilu są zajęcia z robotyzacji.

Do tego dochodzi jeszcze możliwość dofinansowania projektu ze środków Unii Europejskiej. Wydawać by się mogło - „pełnia szczęścia” - i że robotyzacja spawania łukowego powinna rozwijać się lawinowo. Niestety tak nie jest, chociaż trzeba przyznać, że w okresie ostatnich 10 lat liczba zainstalowanych robotów znacznie wzrosła.

\section{Motory i hamulce w rozwoju robotyzacji}

To, co przede wszystkim powoduje potrzebę zastosowania robotów spawalniczych w przemyśle, to korzyści ekonomiczne. Na ten temat sporządzono już wiele opracowań. Jeśli zakład produkcyjny ma w miarę stabilną produkcję, a konstrukcje spełniają warunki do spawania robotem, należy go zastosować, pamiętając o zasadzie, że robot przynosi efekty wtedy, kiedy spawa, a więc pracuje na dwie lub trzy zmiany, a organizacja pracy na stanowisku zrobotyzowanym wygląda tak, że czas jarzenia łuku w ciągu 8 h jest $2 \div 3-k$ rotnie dłuższy niż przy spawaniu ręcznym. Obecne środki techniczne to umożliwiają, i użytkownicy robotów, którzy pamiętają o tej zasadzie, uzyskują zwrot nakładów poniesionych na robotyzację w okresie $1 \div 2$ lat. Do tego dochodzi jakość, powtarzalność, zwiększenie mocy produkcyjnej, skrócenie czasu realizacji kontraktów. Można o zaletach procesów zrobotyzowanych napisać bardzo dużo, ale lepiej zastanowić się, dlaczego robotyzacja nie jest tak powszechna, skoro jej zalety są bezsporne.

Pomińmy aspekt finansowy, bo trudno zachęcać do inwestycji zakład, który jest w upadłości lub znajduje się na granicy płynności finansowej. Spośród wielu czynników na pierwszym miejscu wymieniłbym jednak czynnik ludzki - mentalny.
Jeśli przedsiębiorstwo ma stabilną sprzedaż i nie ma w swojej branży odpowiednio silnej konkurencji, to nie ma wtedy zapotrzebowania na wprowadzanie zmian, w wyniku których uzyska się poprawę efektywności, a zakup robota związany jest $z$ dodatkowym wysiłkiem dla kadry technicznej, z ryzykiem finansowym i wreszcie z odpowiedzialnością za wykonanie konstrukcji spawanej. W tej chwili za jakość złącza odpowiada spawacz, w przypadku robota będzie to programista, który opracował program, czasami jest to spawacz, ale w większości wypadków technolog spawalnik.

Niewłaściwe jest traktowanie robotyzacji w sposób uproszczony, niejako w oderwaniu od procesu spawania. Potencjalni inwestorzy po obejrzeniu w telewizji reportażu z linii zgrzewania nadwozi samochodowych planują zrobotyzować w podobny sposób spawanie metodą MAG - wg recepty dostarczamy blachę w kręgach i profile, a resztę mają zrobić roboty.

Przeciwwagą do powyższej metody „z szerokim gestem" jest podejście siermiężne oszczędnościowe. Przedsiębiorca ma kilkunastoletnie półautomaty z regulacją skokową, dostał większe zamówienie i chce seryjnie produkować np. łyżki do koparek. Do tej pory łyżkę wykonuje się w taki sposób, że spawacz po sczepieniu układał łyżkę na posadzce i klęcząc lub w pozycji kucznej wykonywał spoiny, przewracając łyżkę ręcznie lub żurawiem. Koncepcja w tym przypadku ma polegać na tym, aby w miejscu klęczącego spawacza postawić robot, do którego podłączy się półautomat z regulacją skokową. Najgorsze jest to, że często handlowiec utwierdzi klienta o słuszności jego koncepcji i dostarczy mu bardzo szybko nowy lub używany robot twierdząc, że połączenie z półautomatem i uruchomienie to sprawa tak prosta, że klient poradzi sobie sam. Takie działanie na pewno zatrzyma robotyzację na dłuższy czas.

W obu przypadkach trzeba poświęcić sporo czasu na prezentację, szkolenia i wspólne wypracowanie poprawnej koncepcji robotyzacji.

Jako spawalnik odnoszę często wrażenie, że przedsiębiorcy proces spawania często traktują jak proces niewymagający zbyt dużych nakładów inwestycyjnych. Każdy z przedsiębiorców rozumie potrzebę zakupu obrabiarki ze względu na wymagania zachowania tolerancji wymiarów, podobna sytuacja zachodzi przy procesach malowania ze względu na estetykę wyrobu. O spawaniu i jego robotyzacji bardzo często zaczyna się mówić dopiero pod naciskiem odbiorców produktów, którzy coraz większą uwagę zwracają na estetykę wykonania i powtarzalną jakość spoin.

Opisane zjawiska hamują rozwój robotyzacji w tych obszarach zastosowań, gdzie jej stosowanie jest oczywiste i nie nastręcza większych problemów technicznych.

Poświęćmy trochę czasu tym obszarom problemów technicznych, które mogłyby ułatwić rozwój robotyzacji. 


\section{Sterowalność}

\section{procesem spawania łukowego}

Zagadnienie to jest chyba najbardziej istotne $w$ procesie robotyzacji spawania łukowego. Najprostsze sterowanie polegało na podaniu przez sterowanie robota sygnałów włącz/wyłącz spawanie. Nastawienie parametrów odbywało się ręcznie lub przez proste sterowanie na źródle prądu. Rozwój systemów sterowania w ciągu ostatnich lat odbywał się bardzo dynamicznie i obecnie można bardzo precyzyjnie sterować procesem i kontrolować parametry w zakresie wartości zadanych i wartości rzeczywistych.

Obecnie przy spawaniu zrobotyzowanym dzięki komunikacji sterowania robota ze sterowaniem spawarki można uzyskać precyzyjne opanowanie procesu jarzenia łuku i topienia drutu. Można powiedzieć, że obecna technika zapewnia właściwe sterowanie procesem, ale pomimo pełnej sterowalności nie zawsze udaje się uzyskać zamierzony cel. $\mathrm{Na}$ rysunku 2 przedstawiono złącze teowe ze spoinami pachwinowymi (a) i ze spoiną czołowo pachwinową (b). Wykonanie za pomocą robota spoin pachwinowych nie nastręczy trudności. Ważne jest pytanie, jakie dodatkowe parametry należy wprowadzić do procesu spawania robotem, aby uzyskać równomierny przetop, wypełnienie i lico przy zmieniającym się progu, odstępie i kącie ukosowania. Wiąże się to z wielkością jeziorka i z procesami cieplnymi w złączu. W obecnych warunkach te dwie rzeczy a)

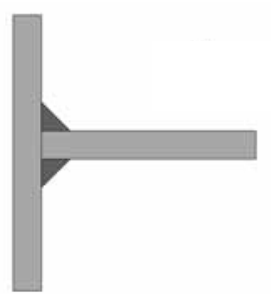

b)

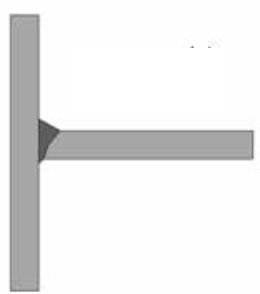

Rys. 2. Złącze teowe: a) spoiny pachwinowe, b) spoina czołowopochwinowa

Fig. 2. Tee joint: a) fillet welds, b) butt-fillet weld

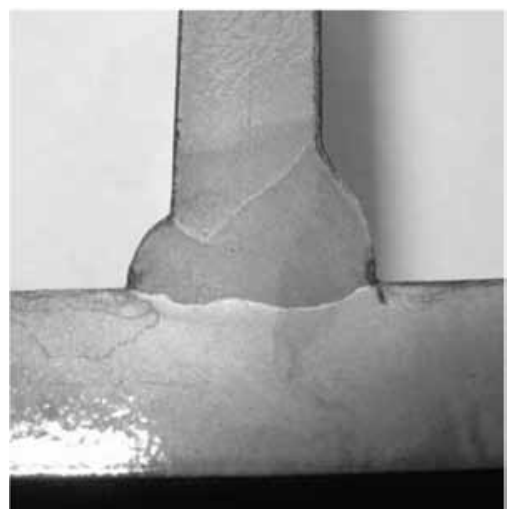

Rys. 3. Złącze wykonane przy zastosowaniu robota metodą Rapid Weld w osłonie $\mathrm{CO}_{2}$, spoina o grubości $10 \mathrm{~mm}$ ułożona w jednym przejściu.

Fig. 3. Joint made using Rapid Weld method in $\mathrm{CO}_{2}$ shielding gas in the robotic station, weld $10 \mathrm{~mm}$ thick placed in a single slag są wielkościami wynikającymi z parametrów spawania. Powstaje pytanie, czy obecny stan wiedzy i techniki umożliwi zaprogramowanie procesu spawania w zależności od odprowadzenia ciepła i wielkości jeziorka, jakie wielkości należy uwzględnić, aby taki proces się udał? Czy jest sens pracować nad tego takimi, czy po prostu należy idealnie montować złącza i stosować np. metodę Rapid Weld i wykonywać złącza jak na rysunku 3.

\section{Wspomaganie procesów programowania robotem}

Obecne systemy off-line do programowania ruchów robota umożliwiają opracowanie programu z użyciem komputera biurowego. Jednak systemy te są skomplikowane i wymagają programisty o dużej wiedzy i doświadczeniu. Programy te przed uruchomieniem należy zawsze sprawdzać pod kątem kolizyjności robota $z$ otoczeniem. Dla ułatwienia pracy systemy te powinny zostać dopracowane w zakresie programowania intuicyjnego, łatwego w obsłudze do wyznaczenia trajektorii robota. Programowanie off-line powinno być tak łatwe jak programowanie on-line. Usprawnienie metody off-line pozwoliłoby na stosowanie robotów $\mathrm{w}$ produkcji jednostkowej i małoseryjnej.

\section{Sensory i ich komunikacja z robotem}

Do ustalenia miejsca wykonania spoiny stosowane są najczęściej sensory kontaktowo-dotykowe lub pomiarowe $z$ użyciem promienia lasera. Do śledzenia rowka w czasie spawania stosowany jest najczęściej sensor łukowy, który przy spawaniu zakosowym dokonuje pomiarów parametrów łuku i koryguje ruchy robota w taki sposób, aby utrzymać nastawione parametry. Do realizacji procesu śledzenia spoiny stosowany jest również sensor laserowy, który przed spawaniem lub podczas spawania dokonuje pomiaru rowka spawalniczego i robot przemieszcza się po wyśledzonej przez sensor trajektorii. Systemy te są bardzo drogie i rzadko stosowane. Udoskonalenie tego systemu w powiązaniu z systemem zadawania parametrów spawania w zależności od kształtu rowka może stworzyć nowe możliwości zastosowania robotów.

\section{Rozwój metod spawania}

Optymalizowanie procesu spawania z wykorzystaniem robotów wymaga wyboru odpowiedniej metody. Do niedawna wybór nie był zbyt bogaty, 
należało wybierać spomiędzy MIG/MAG lub TIG. Obecnie w celu zwiększenia wydajności możemy spawać metodą Tandem lub hybrydowo, a zamiast metody TIG zastosować metodę plazmowo-proszkową. Wydaje się, że poszerzenie obszarów zastosowania robotów przyniesie dalszy rozwój tzw. metod niskoenergetycznych. Metody te w powiązaniu z rozwojem sensoryki i rozwojem programowania mogą umożliwić robotom spawanie warstw przetopowych złączy zakładkowych i czołowych dla cienkich blach. Drugim obszarem, który może przyczynić się do zwiększenia efektywności robotyzacji, jest technika laserowa. Budowa laserów o coraz większej mocy oraz rozwój technik hybrydowych (rys. 4) może spowodować zmiany w podejściu do projektowania węzłów spawanych w konstrukcjach stalowych i stanowi wyzwanie dla robotyzacji.

\section{Podsumowanie}

Przedstawiony, wąski zakres problematyki związany z rozwojem robotyzacji wykazał, że polski przemysł w najbliższych latach powinien wchłonąć dużą ilość stanowisk zrobotyzowanych do spawania w osłonie gazów ochronnych. Rozwój metod spawania oraz różnorodnych technik związanych ze spawaniem będzie poszerzał pole zastosowania robotów.
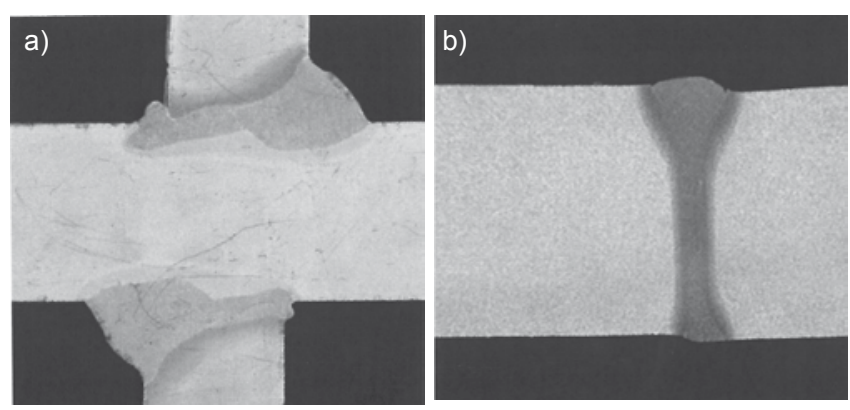

Rys. 4. Makrostruktura złącza blach o grubości $12 \mathrm{~mm}$ wykonanego przez robota metodą hybrydową (laser + MAG): a) złącze krzyżowe, b) złącze doczołowe

Fig. 4. Macrostructure of joint of $12 \mathrm{~mm}$ thick made using robotic hybrid welding method (laser + MIG): a) cruciform joint, b) butt joint

\section{Literatura}

[1] Dąbrowski A:: Zrobotyzowane stanowiska spawalnicze - aspekty praktyczne, Przegląd Spawalnictwa Nr 7-8/2009.

[2] Christian Paul, Lars Hofner - Sensory w robotyzacji.

[3] Materiały informacyjne firmy Cloos.

\section{\& 4METAL.PL}

\section{Ponad 2000 podwykonawców z całego świata}

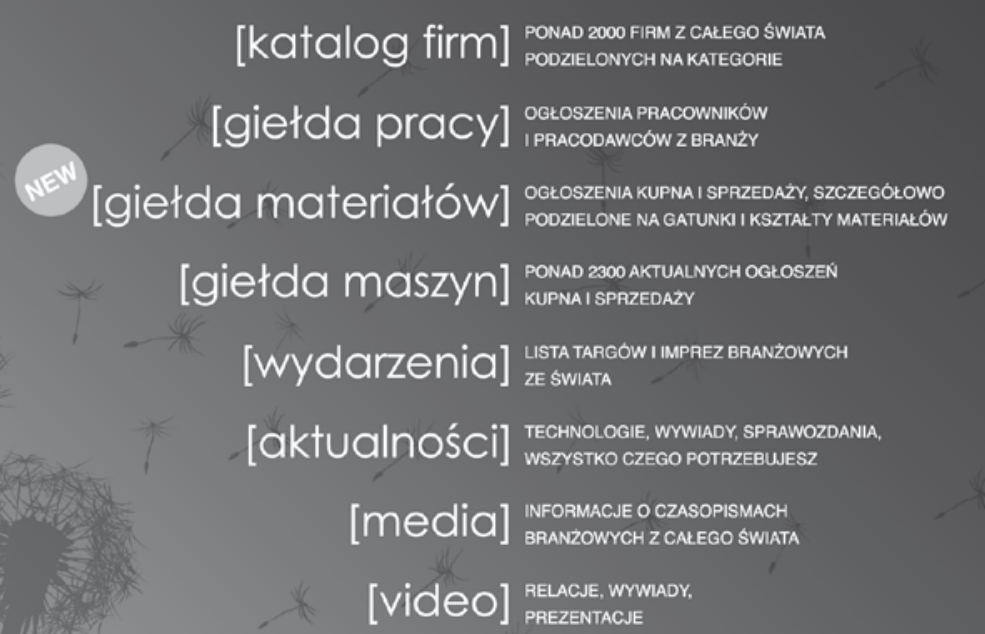

[katalog firm] PONAD 2000 FIRM Z CAEEGO SWMATA

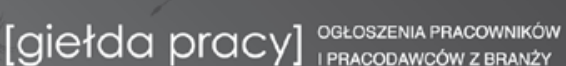

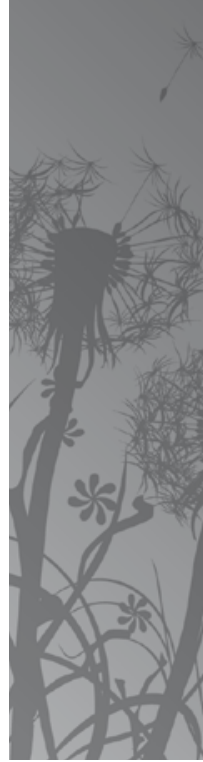

o
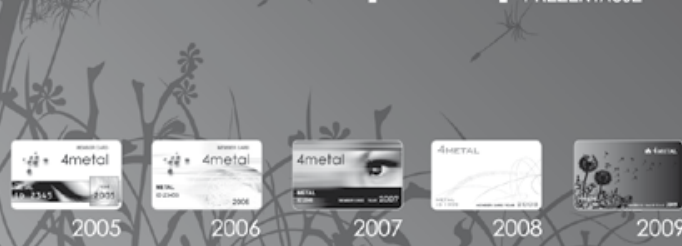
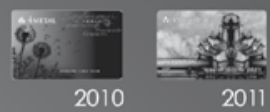

$$
\begin{aligned}
& \text { www.4metal.pl } \\
& =\text { wnw.4metal.de } \\
& \text { wnw.4metal.cz } \\
& \text { 패드 nuw.4metal.com } \\
& \text { www.4metal.nl } \\
& \text { Eww.4metal.at } \\
& \text { [I www.4metal.be } \\
& \text { Enw.4metal.ru } \\
& \text { + nww.4metal.ch } \\
& \text { II nuw.4metalit } \\
& \text { [I. www.4metal.ro } \\
& \text { mww.4metal.hu } \\
& \text { E www.4metal.us }
\end{aligned}
$$

GET THE MEMBERSHIP 